\title{
Two Decades of Croatian Transition: A Retrospective Analysis
}

Nebojsa Stojcic*

Abstract:

Over the past two decades many Central and South East European countries underwent the process of transition from a centrally-planned towards a market economy. Among them, the case of Croatia stands out as particularly interesting. Owing to a number of reasons Croatia had the potential to be among the forerunners of transition. However, in realising this potential the country was constrained by numerous political and social turbulences which made its transition path somewhat unique. The objective of this paper is to explore to what extent the favourable initial conditions of Croatian transition have been exploited over the past two decades. The focus of the analysis is on four dimensions of transition: institutional reforms, macroeconomic performance, changes in economic structure and international trade. The general message yielded by the analysis is that much of Croatia's initial advantage was lost over the past two decades because of war, the unfavourable political climate in the 1990s, late integration into regional, European and global economic institutions and the slow restructuring of enterprises..

Keywords: Croatia, institutional reforms, restructuring, international trade, macroeconomic performance

JEL: P30, P52

DOI: $10.2478 / v 10033-012-0015-5$

\section{Introduction}

The past two decades for Central and South East European countries (CEECs and SEECs) have been marked by their transition from centrally-planned towards market economies. Among them, the case of Croatia stands out as particularly interesting. Prior to transition, economic activity in Croatia was organised through a system which combined planning with market instruments. There were also differences in the structure of the economy, where the manufacturing sector was accompanied by a relatively large service sector. Finally, Croatia traded with both centrally-planned and market economies, the latter accounting for more than half of its overall international trade. These favourable initial conditions indicate that Croatia had the potential to be amongst the forerunners of transition.

In practice, Croatia embarked on transition in an environment characterised by political and social turbulences. With the exception of Bosnia and
Herzegovina, it was the only country that had to deal with transformational recession and to pursue institutional reforms in a war environment. In the post-war period, a set of specific political factors impeded its integration into the EU and other European and international trade organisations. Together with the shortcomings of its privatisation process, these developments delayed the restructuring of Croatian enterprises and eroded their competitiveness in both domestic and foreign markets. In the advanced stage of transition, negative trends were partially reversed as Croatia approached regional, European and global economic associations with higher intensity.

\section{* Nebojsa Stojcic}

Department of Economics and Business Economics University of Dubrovnik, Croatia

E-mail:nstojcic@unidu.hr 


\begin{tabular}{cccccc}
\hline \hline Period & GDP growth & GDP per capita \\
(\%) & growth (\%) & $\begin{array}{c}\text { GDP/ Employment } \\
\text { growth }\end{array}$ & $\begin{array}{c}\text { Inflation (\%) } \\
\text { Export/ Import } \\
\text { ratio }\end{array}$ \\
\hline $1952-1989$ & 5.19 & 4.67 & 1.74 & 59.72 & 9.73 \\
$1952-1971$ & 7.63 & 6.93 & 3.47 & 19.70 & 0.75 \\
$1972-1979$ & 5.41 & 5.00 & 1.52 & 244.32 & 0.61 \\
$1980-1989$ & -0.75 & -1.12 & -1.80 & 0.77 \\
\hline \hline
\end{tabular}

Table 1: Main macroeconomic aggregates: Croatia 1952-1989

Source: Own calculations based on data from the Croatian Statistical Office (DZS) and Druzic (2006).

The objective of this paper is to explore to what extent the favourable initial conditions of Croatian transition have been exploited over past two decades. The analysis focuses on four dimensions of transition: institutional reforms, macroeconomic performance, changes in economic structure and international trade. To this end, Section 2 explains why Croatia was expected to be amongst the forerunners of transition. Section 3 will then investigate the major changes that took place in the previously mentioned dimensions during the transition period and compare the Croatian experience with that of other transition economies. Finally, a summary of findings will be presented in Section 4.

\section{The Croatian Economy before Transition}

Before transition, Croatia had a number of distinctive characteristics compared to other centrally-planned economies. The country followed a 'liberal' model of central-planning, known as self-managed socialism, which combined instruments of both planning and the market. In general, and by many criteria, the country was closer to the standards of industrialised market economies than any other socialist country. In this context, it is possible to track the main features of the Croatian economy before transition along four main areas: the characteristics of its institutional framework, macroeconomic performance, the structure of its economy and international trade.

\subsection{Institutional Setting}

As part of the former Yugoslavia, Croatia practised a liberal model of socialism known as 'socialist selfmanagement'. Formally, economic activity was coordinated through plans but these plans were more of an indicative than of a binding nature and enterprises had to rely, by and large, on market forces when making decisions about their activities (Gros and Steinherr, 1995). The ownership rights over the means of production were vested in all citizens but the management over such social property and responsibility for the performance of enterprises were delegated to workers. In such a setting, the managers of enterprises had the opportunity and incentive to show initiative and to respond to market stimulus. All in all, the market forces were present to a much higher extent than in any other centrally-planned economy until the fall of the system. This is particularly true for the period between 1952 and 1972, which was characterised with decentralisation of decision-making and price and trade liberalisation which enhanced managerial initiatives (Lyndall, 1984; Druzic, 2006). In that respect it can be argued that Croatia's transition to a market economy has been underway since the 1950s.

\subsection{Macroeconomic Performance}

From 1952, the year with the first available post-WW2 statistical data on Croatian macroeconomic performance until 1989, when the socialist period came to an end and the transition period started, the Croatian economy was growing at an average annual rate of $5.2 \%$ (Table 1). For comparison, the average rate of growth in OECD countries between 1960 and 1989 was 3.93\%. The productivity of labour in that period was growing at a rate of $1.7 \%$ per year while the export/import ratio averaged around $75 \%$. The only exception to this positive picture was inflation, which had an average annual rate of $60 \%$. However, averaging over such a long period may hide the actual variations in macroeconomic aggregates in particular sub-periods. To this end, the post-war period may be divided into three distinguishable periods; the liberalisation (1952-1971), the retreat from the market (1972-1979) and finally the period of economic decline (1980-1989) (Druzic, 2006). 

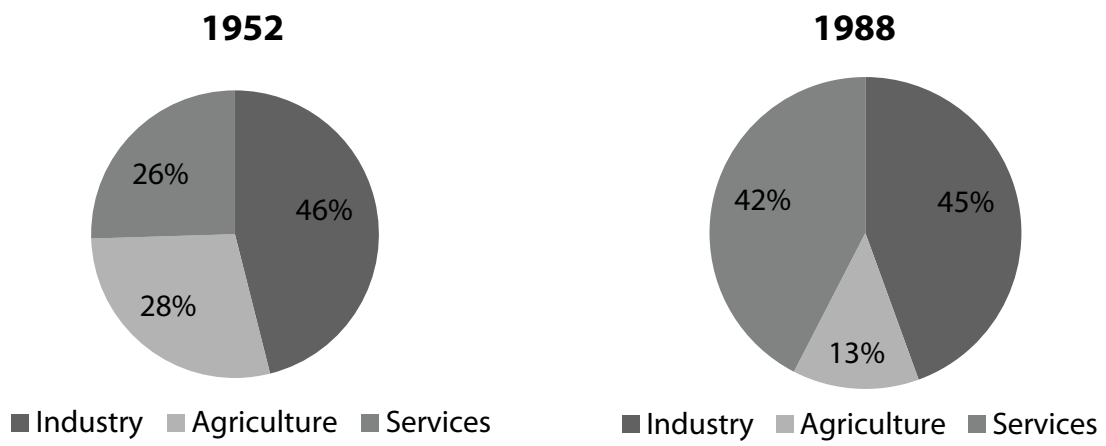

Figure 1: The structure of the Croatian economy, 1952-1988

Source: Federal Statistics Bureau of Yugoslavia, (SZS) 1989 and DZS, 1990 Industry includes mining and construction

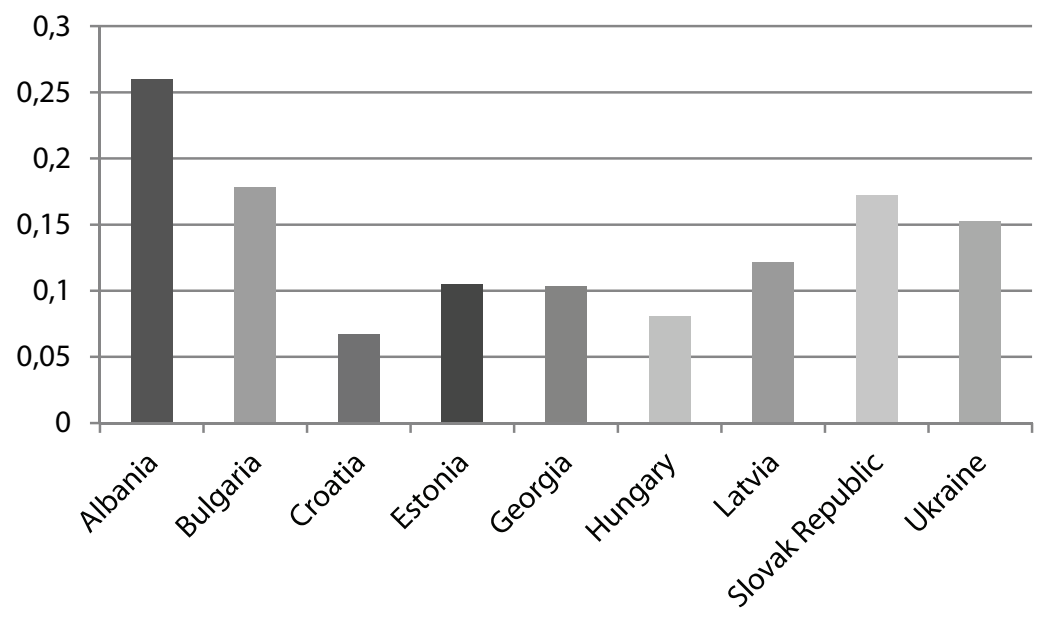

Figure 2: Structural similarity of selected centrally-planned economies and EU15 in 1988

Source: Own calculations based on data from DZS (1990) and WDI World Bank (2010)

The highest rates of growth were recorded in the years of liberalisation (1952-1971) and they were accompanied by rising labour productivity (Table 1$)$. The years that followed (1972-1979) were characterised by a slowdown which turned into a decline in the 1980s. The coverage of exports with imports was throughout this entire period above $60 \%$, and particularly high in the years of the institutional reforms (1960s) and in the second half of 1980s due to the combination of increased exports and administrative control over imports. However, an acute problem of the Croatian economy was inflation. The rise of prices started after 1960 due to the fact that price and trade liberalisation increased the prices of raw materials and agricultural products. High rates of inflation were also recorded in the years of oil shocks (1973-74 and 1979), suggesting that Croatia, as other centrally-planned economies, was sensitive to changes in the prices of energy and raw materials. However, the highest rates of inflation were recorded in the last years of the socialist era.' This was caused by a combination of factors of which the most important were structural disproportions, the high share of foreign debt and oil shocks (Gros and Steinherr, 1995).

\subsection{Economic Structure}

Croatia entered central planning as a predominantly industrial and agricultural economy with these sectors accounting for $46 \%$ and $28 \%$ of overall output, respectively (Figure 1). In the years that followed, the industrialisation of the economy continued and in 1988 industry accounted for $45 \%$ of the overall output. By this time, the services had become the second largest sector, with their share increasing to $42 \%$ (Figure 1).

The comparison of the economic structure of Croatia and several other centrally-planned economies (for which 
data were available) with that of the EU15 in 1988 using the index of structural convergence developed by Thiessen and Gregory (2007) shows that in structural terms Croatia was closer to EU15 countries than any other centrally planned economy (Figure 2).i It can be concluded that favourable economic policies and institutional circumstances had facilitated the gradual emergence of an economic structure typical of market economies.

\subsection{International Trade}

The distinctive feature of the Croatian trade pattern in comparison to other centrally-planned economies was its much stronger orientation to West European markets. In 1989, more than half of both Croatian exports and imports were accounted for by trade with market economies, mainly West European (Table 2). Croatia's main trading partners at the time were Italy, Germany (Federal Republic) and the Soviet Union (DZS, 1990). Together, these three countries accounted for one third of Croatian imports and absorbed nearly half of its exports.

\begin{tabular}{lcc}
\hline \hline & Flow & \\
& Export & Import \\
Destination & & \\
\hline Market Economies (MEs) & 0.54 & 0.53 \\
Western Europe & 0.46 & 0.43 \\
Other ME & 0.08 & 0.10 \\
Centrally-Planned Economies (CPEs) & 0.29 & 0.25 \\
East European CPE & 0.29 & 0.25 \\
Other CPE & 0.01 & 0.01 \\
Developing Countries & 0.16 & 0.22 \\
\hline \hline
\end{tabular}

Table 2: Distribution of Croatian international trade in 1989 Source: DZS, 1990

Table 3 shows the sectoral distribution of the international trade of Croatia and the EU15 countries with the rest of the world in 1988.iii At that time, over $53 \%$ of Croatia's exports were concentrated in two sectors (6 and 7 - 'manufactured goods' and 'machinery and equipment'). These two sectors also accounted for the largest share of EU15's exports (almost 53\%). Two sectors ( 3 and 7 = 'energy and raw materials' and 'machinery and equipment') accounted for the bulk of Croatia's imports (nearly $47 \%$ ). Given that $70-75 \%$ of Croatia's trade was conducted with Western Europe and non-socialist countries (Table 2), the sectoral distribution of its exports and its similarity with the market economies of EU15 indicates that Croatian industries were influenced by, and responded to, international market trends.

\begin{tabular}{ccccc}
\hline \hline Sector & $\begin{array}{c}\text { Croatia } \\
\text { Export }\end{array}$ & $\begin{array}{c}\text { Croatia } \\
\text { Import }\end{array}$ & $\begin{array}{c}\text { EU15 } \\
\text { Export }\end{array}$ & $\begin{array}{c}\text { EU15 } \\
\text { Import }\end{array}$ \\
\hline 0 & 11.4 & 9.1 & 10.3 & 9.3 \\
1 & 0.6 & 0.1 & 1.8 & 1.0 \\
2 & 5.8 & 9.3 & 5.5 & 5.9 \\
3 & 3.6 & 26.3 & 3.2 & 7.4 \\
4 & 0.1 & 0.3 & 0.5 & 0.4 \\
5 & 10.4 & 18.8 & 10.4 & 10.8 \\
6 & 21.5 & 11.6 & 22.6 & 18.1 \\
7 & 31.9 & 20.3 & 30.2 & 33.5 \\
8 & 14.6 & 4.3 & 14.3 & 11.9 \\
9 & 0.1 & 0.0 & 1.4 & 1.6 \\
\hline \hline
\end{tabular}

Table 3: Sectoral distribution of exports and imports of Croatia and EU15 in 1988 (\%)

Source: Own calculations based on UN Comext database and SZS (1989)

Bringing all the findings from this section together, several reasons can be identified as to why Croatia was expected to be among the forerunners of transition. First, even before transition Croatia was a semi-market economy with many functioning market instruments which had yet to be introduced in other centrallyplanned economies. Second, in structural terms, Croatia was closer to European market economies than most of the other centrally planned economies. Third, Croatian producers have been predominantly oriented towards international trade on West European markets and their export was in line with import demand of that market.

\section{Croatian Economy in Transition}

The transition in Croatia formally started in 1989 with the introduction of several laws that permitted the creation of new private businesses and the full transfer of ownership over socially owned means of production to employees and outside owners. As the EBRD indices of institutional reforms (Figure 3) show, some degree of price and trade liberalisation and small entrepreneurship existed even in 1989 before the break-up of Yugoslavia. However, these favourable initial conditions were offset by the political and social turmoil, including the war that followed Croatia's declaration of independence from Yugoslavia and the subsequent dissolution of this country. The initial transformation policies aimed at facilitating Croatia's transition to a market economy were 


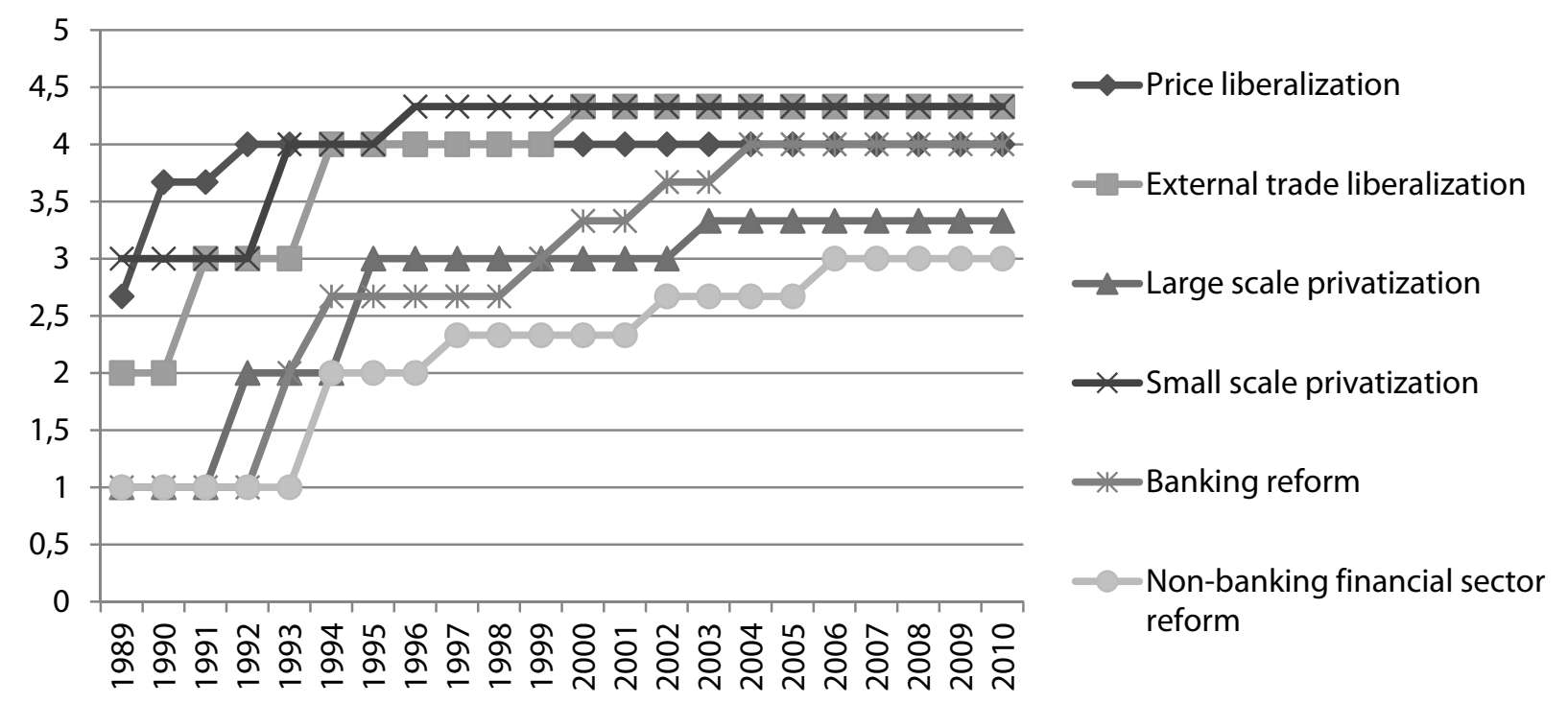

Figure 3: Indices of the progress in institutional reforms in Croatia, 1989-2007 Source: EBRD Transition report (various years)

undertaken under conditions of war, with an inflow of refugees and consequent economic, social and political problems (Bartlett, 2003). In addition to war, specific political circumstances during the second half of the 1990s impeded Croatia's EU accession as well as integration into international economic and political associations such as the Central European Free Trade Agreement (CEFTA), World Trade Organisation (WTO), etc. These factors did not facilitate the restructuring of enterprises whose competitiveness declined in this period (Nikic, 2003).

\subsection{Institutional Framework}

As a semi-market economy Croatia had the advantage that the extent of institutional reforms that needed to be undertaken was less than in other transition countries. The institutional reforms in the transition period were the continuation of reform processes which started in the 1960s and continued in the second half of the 1980s. The most important reforms were undertaken in the first half of the 1990s. By 1992, price controls were restricted to natural monopolies, highly concentrated industries and some sectors such as agriculture and shipbuilding. iv Full current account convertibility and internal convertibility were established in 1993 thus enabling the free purchase of foreign currencies by legal and private subjects. Trade liberalisation was gradual and, by 1996, import quotas and non-tariff instruments were replaced by a set of tariffs typical of market economies (Skreb, 1995; Bartlett, 2003).
The capital account was liberalized only in 2007, in which respect Croatia was more conservative than other CEECs (Babic, 2002). Croatia experimented with several exchange rate mechanisms from the real exchange rate regime (REER) inherited from Yugoslavia to the fixed exchange rate regime in 1991, to the floating regime in 1992 and to a crawling peg exchange rate regime introduced in 1993, pegging the domestic currency first to the Deutschmark (DEM) and then to the Euro (Payne, 2000). Figure 3 shows the progress of institutional reforms in the post-transition period.

In the first years of the transition Croatia benefited from preferential trade agreements signed between the EU and Yugoslavia in the 1980s. However, due to various political obstacles, the integration in international trade flows in later years was slower than in other CEECs. Membership in the World Trade Organization (WTO) was achieved in 2000 while the Association Agreement with EU which enabled CEECs to export their products to the EU market under preferential terms was signed in 2001. ${ }^{\mathrm{v}}$ Finally, given that Croatia was not part of the Central European Free Trade Agreement (CEFTA) until 2003, her access to markets of other CEECs was impeded. From 2000, preferential trade agreements were signed with almost all CEEC members and according to Skuflic (2005), 95\% of Croatia's trade in 2005 was covered with bilateral trade agreements.

In addition to the previously mentioned laws from 1989 that allowed the creation of private and the privatisation of socially owned enterprises, the law on the 
Transformation of Socially Owned Assets was passed in 1991, which further facilitated the replacement of social ownership by private ownership. In the next two years the bulk of companies were privatised through direct sales to employees, Croatian citizens and Croatian and foreign legal entities. The remaining shares from this round were sold from 1994 to 1997 on the basis of contractual sales or they were distributed to selected institutions and groups such as health and pension funds, war veterans, etc. By 1998, 96\% of total capital earmarked for privatisation was privatized in this manner (Druzic, 2006). Between 1998 and 2000 half of the remaining shares were then distributed through voucher privatization to selected social categories. Finally, in the fourth stage, after 2000, the shares in the remaining nonprivatized companies and some strategic companies, mainly public utilities which were left out of the earlier stages of privatization, were offered either through the stock-exchange or directly to strategic partners.

Although ownership was transferred formally to the private sector, the state continued to remain in control of the economy through several indirect channels such as state companies or state-owned banks (Bartlett, 2003). Furthermore, the privatization often lacked transparency and the ownership of some of the most profitable enterprises was transferred to individuals who had close ties to the governing party in contravention of the law (Bartlett, 2003). Also, 100 of the most important large companies were left to be privatized in later periods. The new owners of privatised companies often lacked the vision, knowledge and capital to transform enterprises into efficient companies capable of competing in a market economy. As a consequence, many profitable and potentially profitable enterprises were eventually returned to the Croatian Privatization Fund (CPF) as lossmaking companies ready for liquidation. An audit of the privatization programme by the State Audit Office in 2004 found that $64 \%$ of privatized companies failed to achieve goals stated before privatization (State Audit Office, 2004). In addition, the discounted sale of shares to employees proved to be unsuccessful as in many cases employees were not able to pay for their shares. According to Gregurek (2001), by 1999 only $26 \%$ of shares purchased by employees were paid for and about $60 \%$ of contracts between CPF and employees had to be terminated.

The reforms in the banking sector started in 1991 with measures aimed at freeing banks from accumulated bad loans. From 1993, the Croatian National Bank (HNB) was given autonomy and it was vested with the duty to maintain the stability and liquidity of the financial system. Its supervisory powers were further increased with the new banking law in 1999. Furthermore, ceilings were introduced on the credit activities of business banks and government borrowing from the central bank. The reforms of the banking sector continued in two waves, first in 1995 when four major loss-making banks were rehabilitated and in 1999 when the new banking law initiating the bankruptcy of some banks and the privatization of others was passed (Bartlett, 2003).

During the transition period, changes have also taken place in the number of banks and in the ownership structure of the banking sector. In 1993, the Croatian banking sector consisted of 25 state-owned banks and 18 banks under private domestic ownership (HNB, 2010). The number of banks rose until 1998, when the total reached 60 banks, of which 42 were under domestic private ownership, 10 were under foreign ownership and 8 were owned by the state. Since then, the number of banks has been falling and by 2007 , the total had fallen to 33 banks, 2 owned by the state, 16 by foreign owners and 15 by domestic private owners. After 2000, the share of the state in the assets of the banking sector was reduced to $5 \%$, and has varied between $4 \%$ and $5 \%$ ever since. Among private banks, the share of foreign owners in the assets of the banking sector has been rising and, since 2002 , over $90 \%$ of the Croatian banking sector was under foreign ownership (HNB, 2010).

The stock-exchange was established as early as 1991 , but the stock market started to gain importance from 1998 after voucher privatization, when newly established Privatization Investment Funds (PIFs) entered the market and began trading with shares of privatized enterprises. The number of funds and their diversity increased over the years and at the end of 2007 there were 100 openend and 9 closed-end investment funds. After 2000, the insurance sector was also liberalized and in 2007 there were 27 insurance companies in Croatia. Finally, the reform of pension funds was undertaken between 1999 and 2002 when the former retirement fund was substituted by the three pillar pension model consisting of mandatory personal retirement accounts, mandatory private retirement schemes, and optional private savings for the purpose of retirement.

To sum up, two sub-periods can be distinguished in Croatia's institutional development during transition. Between 1991 and 1999 Croatia introduced all major mechanisms required for the establishment of a 


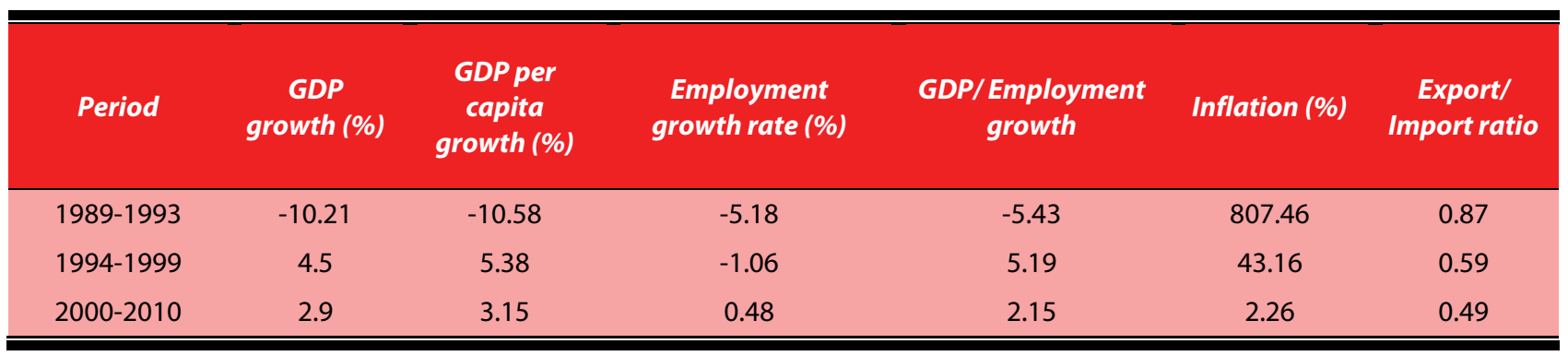

Table 4: Croatia's main macroeconomic aggregates: Annual averages, 1989-2010

Source: DZS and HNB

functioning market economy. However, due to the specific nature of the Croatian transition the success of these reforms was only partial and in many aspects Croatia fell behind other CEECs. In the second period, after 2000, Croatia made significant progress to regain its position in the group of advanced CEECs. This primarily relates to the process of integration in international and regional trade arrangements and developments in the financial sector. In this context it can be stated that the institutional framework of a market economy was fully created at an advanced stage of transition.

\subsection{Macroeconomic Performance}

At the beginning of the transition, the Croatian economy demonstrated behaviour typical of transition economies. The decline in output was accompanied by a decline in employment and rising inflation. However, the transformational recession was amplified with the war and the break-up of linkages with the markets of the former Yugoslavia. Between 1989 and 1993 the GDP fell at an average annual rate of $10 \%$ and in 1993 it was at $60 \%$ of its pre-transition level (Table 4). Such output decline is comparable only to that of some CIS and Baltic countries (Fischer et al., 1996). Due to a transformational recession and the destruction of many industrial capacities in the first years of the war, the number of employed persons fell from 1.6 million to 1.23 million, i.e. a decline of almost $25 \%$ (Druzic, 2006). The only aspect of macroeconomic performance that developed in a favourable direction in this period was the export/import ratio, which was sustained at a level of nearly $90 \%$. However, these developments should be interpreted with caution as at the time Croatia was under unofficial sanctions which artificially decreased imports. Moreover, imports in this period included a considerable amount of military equipment which was not registered in the official import statistics (Druzic, 2006).
Inflation, inherited from the 1980s, reached its peak between 1989 and 1993 when the average annual rate of inflation was over $800 \%$ (Table 4), substantially above the inflation rates in CEECs and in line with CIS, Macedonia and some Baltic countries. The first attempts to curb inflation were made in 1989 when the annual rate of inflation was running at $1200 \%$, but these measures yielded only temporary success and inflation again started to rise after the disintegration of Yugoslavia and the onslaught of the war. By this time, inflation was further fuelled by the attempts of monetary authorities to build foreign currency reserves (Bartlett, 2003). ${ }^{\text {vi }}$ As a consequence, inflation reached its peak in October 1993 when its annual level amounted to over $1400 \%$.

The recovery of the economy started in the second half of 1993 when the government introduced a stabilisation plan which had four main objectives: to curb inflation, to initiate restructuring of the real sector and to rehabilitate the financial sector, and to create foundations for sustainable growth of the economy in the long run. In 1994 the rate of inflation fell to $107 \%$ and in the following five years it was brought down to an average of $4.46 \%$ per annum. On a wave of post-war recovery and stabilization, the Croatian economy started to grow and the average annual rate of growth of GDP and GDP per capita reached $4.5 \%$ and $5.38 \%$ respectively, which was in line with other CEECs. As employment continued to fall at about $1 \%$ annually, overall labour productivity increased at a rate of $5 \%$ per year (Table 4 ).

The success of macroeconomic stabilization, however, was not followed by another element of the stabilization package, namely enterprise restructuring. The failures of privatization, the weak discipline in the banking sector and the specific political environment of the 1990s impeded the restructuring process which eventually eroded the competitiveness of domestic enterprises (Nikic, 2003). This was particularly visible in international trade where the ratio of export to import fell to $60 \%$ (Table 4). The expansion of the economy and the post- 


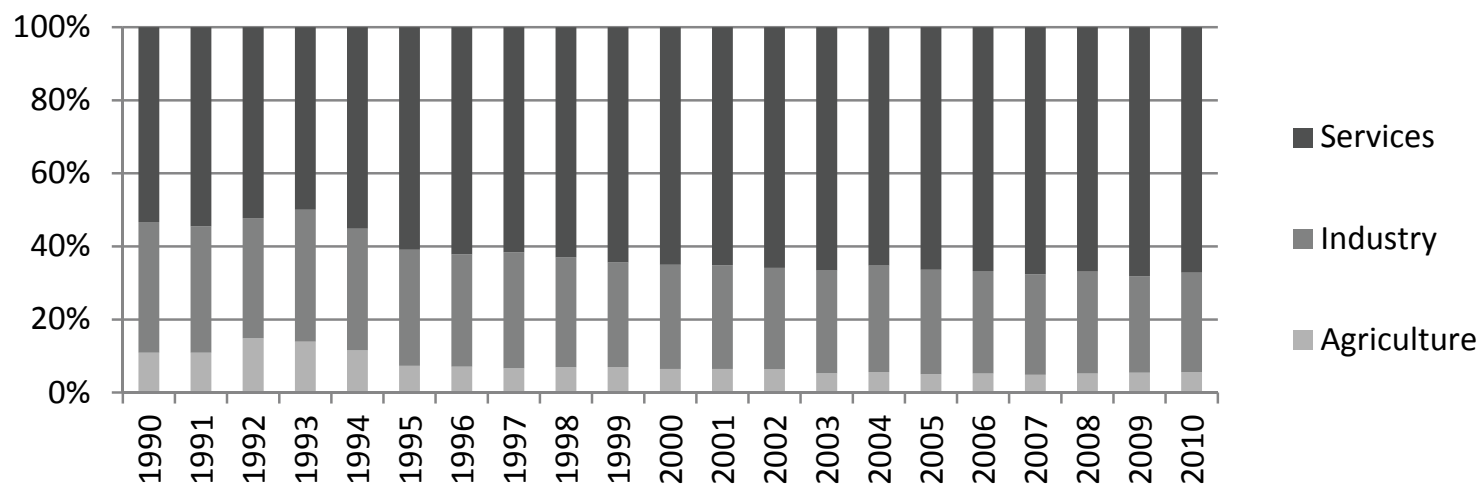

Figure 4: The structure of the Croatian economy ( $\%$ of GDP), 1990-2010

Source: WDI, World Bank, 2012

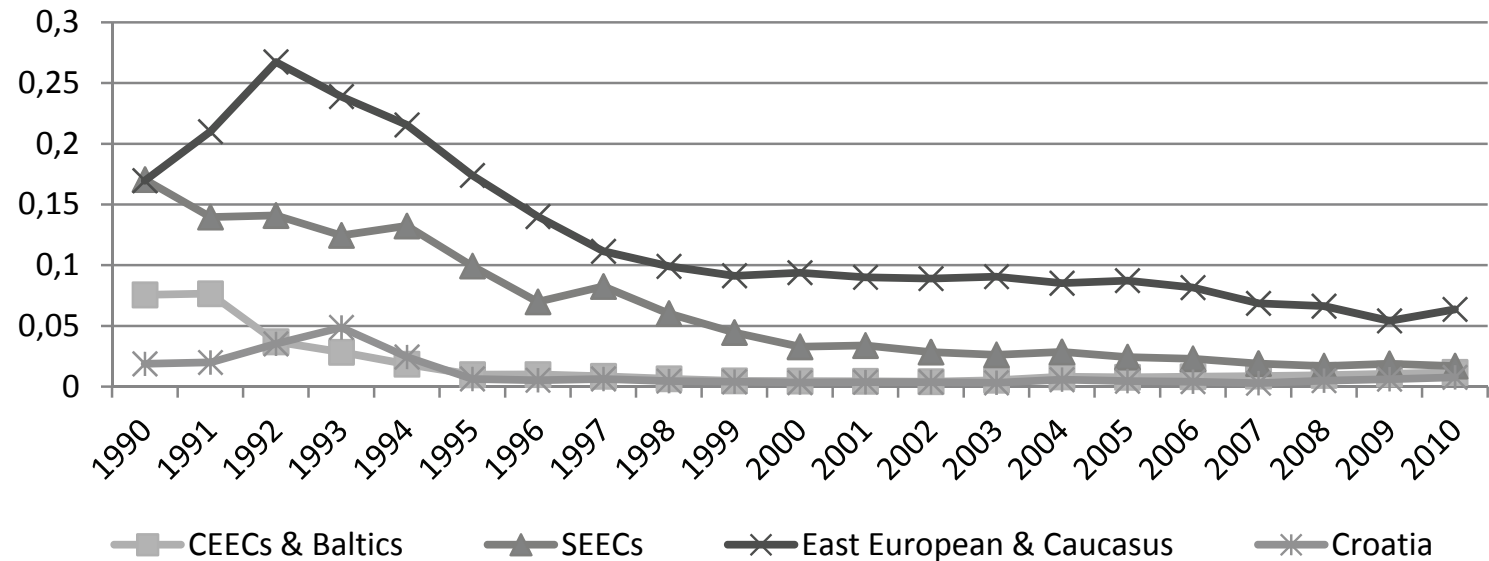

Figure 5: Structural convergence of transition economies, 1990-2010

Source: Own calculations based on WDI World Bank (2012)

war recovery were accompanied by a rise in imports for both consumption and investment purposes. As domestic export stagnated, Croatia was eventually transformed into an import led economy (Bartlett, 2003).

Between 2000 and 2010, all main macroeconomic aggregates recorded positive trends. Growth of GDP and GDP per capita was somewhat lower than in other CEECs but Croatia reached its pre-transition level of output in 2003 (EBRD, 2007). The growth of output was accompanied by growth in employment $(0.48 \%)$ which was higher than in other CEECs $(0.38 \%)$ and by a growth of labour productivity (2.15\%). Also, through the entire period, inflation remained at around $3 \%$, below the rate of inflation in other CEECs (4.8\%) (EBRD, 2011). However, the export/import ratio fell to an average of about $50 \%$ (Table 4).

To sum up, the transformational recession in Croatia was particularly strong, with a decline in output and high inflation that were more comparable with the experiences of CIS countries than with those of CEECs. In the years after the introduction of the stabilization programme, Croatia managed to restore macroeconomic stability and achieve rates of growth typical for CEECs. However, the stabilization and expansion of the economy were not accompanied by the restructuring of enterprises which eroded the competitiveness of Croatian exports and eventually transformed Croatia into an import-led economy.

\subsection{Structural Changes}

Before transition, economic activity in Croatia was concentrated in the manufacturing and service sectors. During the period of transformational recession, the service sector suffered from a particularly large contraction, mainly due to the decline in tourism. In 1991, the fall in the number of tourist arrivals was estimated at 85\% (Bartlett, 2003). However, as transformational 


\begin{tabular}{|c|c|c|c|c|}
\hline $\begin{array}{l}\text { Industry } \\
\text { Code }\end{array}$ & Industry Name & 1995 & 2005 & $\begin{array}{l}2005 / 1995 \\
\text { (p.p.) }\end{array}$ \\
\hline 15 & Food products and beverages & $19.3 \%$ & $20.2 \%$ & 5.1 \\
\hline 16 & Tobacco products & $2.4 \%$ & $2.5 \%$ & 3.0 \\
\hline 17 & Textiles & $2.8 \%$ & $1.7 \%$ & -39.7 \\
\hline 18 & Wearing apparel; Dressing and dyeing of fur & $5.6 \%$ & $3.8 \%$ & -32.3 \\
\hline 19 & $\begin{array}{l}\text { Tanning and dressing of leather; luggage, handbags, saddler, harness, } \\
\text { footwear }\end{array}$ & $2.2 \%$ & $1.3 \%$ & -40.4 \\
\hline 20 & Products of wood and cork, except furniture; articles of straw and plaiting & $2.8 \%$ & $2.9 \%$ & 3.1 \\
\hline 21 & Pulp, paper and paper products & $2.7 \%$ & $2.0 \%$ & -23.6 \\
\hline 22 & Publishing, printing and reproduction of recorded media & $6.6 \%$ & $5.8 \%$ & -12.4 \\
\hline 23 & Coke, refined petroleum products and nuclear fuel & $10.3 \%$ & $10.9 \%$ & 5.8 \\
\hline 24 & Chemicals and chemical products & $11.8 \%$ & $8.1 \%$ & -32.0 \\
\hline 25 & Rubber and plastic products & $2.4 \%$ & $2.4 \%$ & 1.2 \\
\hline 26 & Other non-metallic mineral products & $4.4 \%$ & $7.2 \%$ & 61.8 \\
\hline 27 & Basic metals & $1.9 \%$ & $1.7 \%$ & -15.4 \\
\hline 28 & Fabricated metal products, except machinery and equipment & $5.9 \%$ & $7.5 \%$ & 27.2 \\
\hline 29 & Machinery and equipment n.e.c. & $3.4 \%$ & $3.4 \%$ & 0.9 \\
\hline 30 & Office machinery and computers & $0.9 \%$ & $1.0 \%$ & 23.2 \\
\hline 31 & Electrical machinery and apparatus n.e.c. & $3.9 \%$ & $4.2 \%$ & 7.4 \\
\hline 32 & Radio, television and communication equipment and apparatus & $2.2 \%$ & $2.3 \%$ & 3.8 \\
\hline 33 & Medical, precision and optical instruments, watches and clocks & $0.9 \%$ & $0.8 \%$ & -15.2 \\
\hline 34 & Motor vehicles, trailers and semi-trailers & $0.8 \%$ & $1.1 \%$ & 30.7 \\
\hline 35 & Other transport equipment & $2.9 \%$ & $5.4 \%$ & 83.1 \\
\hline 36 & Furniture; manufacturing n.e.c. & $3.2 \%$ & $2.9 \%$ & -6.4 \\
\hline 37 & Recycling & $0.6 \%$ & $0.8 \%$ & 43.3 \\
\hline
\end{tabular}

Table 5: Industry value added as \% of manufacturing in Croatia, 1995-2005

Source: DZS, 1997 and 2008

recession and the war had affected the entire economy, the contraction of services did not produce major changes in its structure. In 1993, the year when output fall reached its bottom, the service sector accounted for nearly $50 \%$ of the entire value added in the Croatian economy, compared with $54 \%$ in 1990 . It was followed by industry (36\%), whose share slightly increased from $35 \%$ in 1990, and agriculture whose share increased from $10 \%$ in 1990 to $14 \%$ in 1993. Figure 4 shows the change in the structure of the economy throughout the transition period.

In the years after the introduction of the stabilization programme and during the post-war recovery (19941995), the share of the service sector in the economy increased to $64 \%$ in 1999 and by another $5 \%$ by 2010 (Figure 4). The share of industry was reduced to $28 \%$, while the share of agriculture fell to $6 \%$ by 2010 . The structure of the Croatian economy in this period was shaped by the end of the war and regional conflict, which boosted domestic tourism and increased the share of services to levels higher than pre-transition levels. However, it is also likely that the combination of privatization failures, the difficulties of access to the markets of the EU and CEECs, and the penetration of imports eroded the competitiveness of the Croatian manufacturing sector and reduced its share in the overall economy. A comparison of the structural similarity between transition economies and Croatia on the one hand and the EU15 economies on the other indicates that Croatia soon assumed a pattern which was much closer to that of market economies than to its centrally-planned counterparts (Figure 5). In that respect Croatia was closer to the EU15 countries than the group of advanced CEECs. 


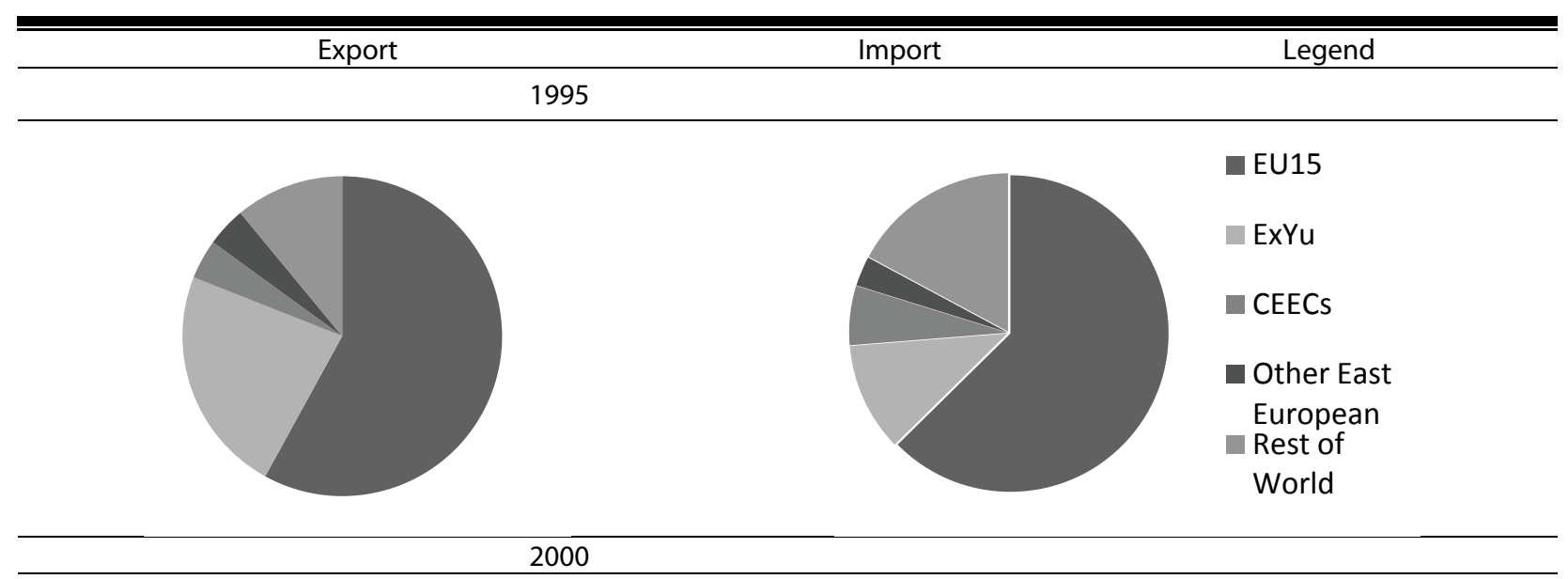
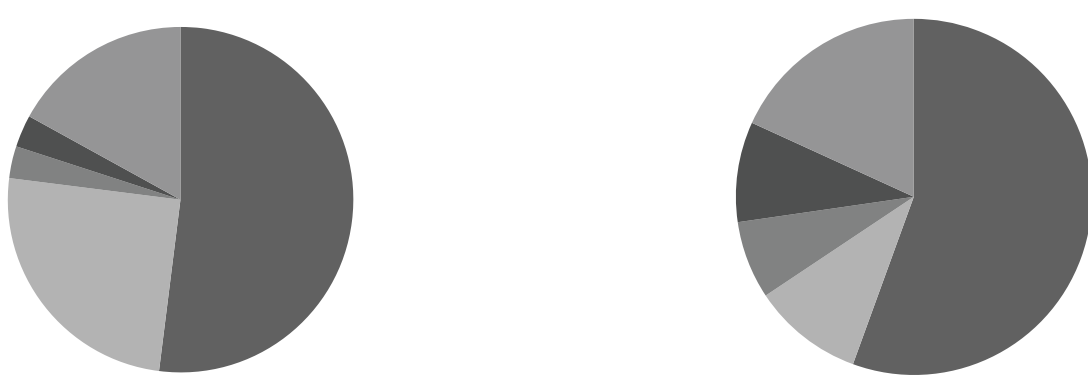

EU15

ExYu

CEECS

Other East

European

Rest of

World

\section{7}
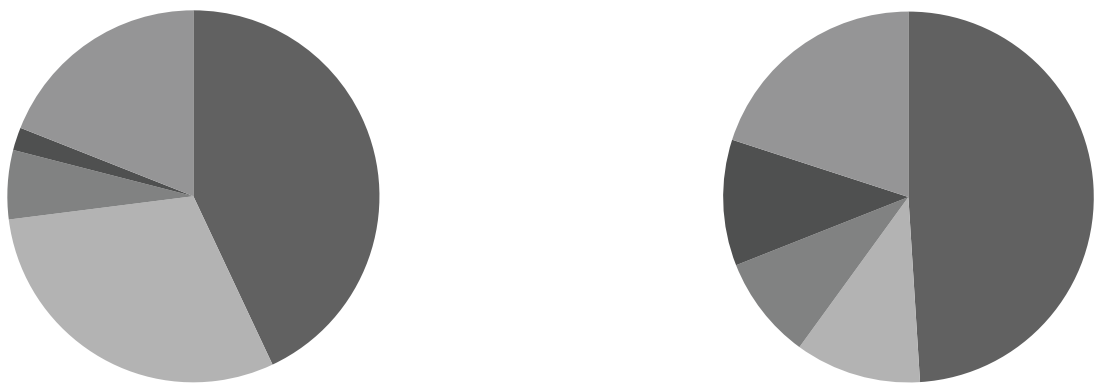

EU15

ExYu

CEECS

Other East

European

Rest of

World

\footnotetext{
Figure.6: \% of Croatian trade by main trading partners, 1995-2007

Source: IMF DOTS Database

ExYu group includes Slovenia, Bosnia and Herzegovina, Serbia, Montenegro and Macedonia

CEECs group includes Bulgaria, Czech Republic, Hungary, Poland, Romania, Slovak Republic, Estonia, Latvia and Lithuania

Other East European group includes CIS countries, Moldova, Albania and Georgia
}

A closer look at the components of the manufacturing sector, presented in Table 5, indicates that between 1995 and 2005 the food industry, the manufacture of coke, petroleum and nuclear fuels and the chemical industry accounted for more than $40 \%$ of the value added in this sector. The industries that have enjoyed the highest rate of growth in this period were the manufacture of transport equipment (83 p.p.), the manufacture of other non-metallic mineral products (61 p.p.) and recycling (43.32 p.p.). However, together these three industries accounted for only $13 \%$ of the total value added in manufacturing. On the other hand, the fastest declining industries in the period of transition were the manufacture of leather and leather products (-40.35 p.p.), manufacture of textiles (-40 p.p.), manufacture of apparel, the dressing and dyeing of fur (-32 p.p.) and the chemical industry (-32 p.p.). In 1995 these four industries together accounted for $22 \%$ of the total value added in manufacturing whereas by 2005 their share had fallen to $14 \%$. 
The division of industries from Table 5 by their technological intensity into low, medium-low, mediumhigh and high technology intensive industries (OECD, 2007) reveals that the industries with the largest share in the Croatian manufacturing come from low (food industry), medium-low (coke-petroleum and nuclear fuels) and medium-high (chemical industry) technologyintensive industries. Such a dispersed pattern may imply either a lack of specialization or it may also signal that, even in an advanced stage of transition, the manufacturing sector was still undergoing structural changes. The latter explanation seems more plausible if we note that the three largest losers (in terms of their shares in value added of the manufacturing sector) were low-technology intensive industries, while the five biggest gainers in transition four were from the mediumlow and medium-high technology intensive industries.

Summing all of these findings it can be concluded that during the transition period Croatia has gradually approached the structure of a market-style economy. After the war and the initial transformational recession, the share of the service sector increased to above its pretransition levels and Croatia became closer to the structural pattern of EU15 countries than any of the three major groups of transition countries. However, it needs to be underlined that within the manufacturing sector, the low-technology intensive industries retained the largest share. Moreover, the restructuring of Croatian enterprises in the early transition period took place in a more hostile institutional environment than in other CEECs.

\subsection{International Trade}

As has been already explained in Section 2, in the first years of transition Croatia benefited from a Trade and Cooperation Agreement signed between the EU and Yugoslavia in the 1980s. In later years the lack of the Association Agreement deprived Croatia of preferential access to EU markets that was offered to many other transition countries. The exporters from transition economies which had an Association Agreement with EU were discouraged to source their inputs in Croatia, as these agreements required that their exports to the EU market must contain minimum levels of input originating either in the EU, or in Association Agreement countries. Similarly, the late signing of the CEFTA agreement impeded access by Croatian producers to CEECs' markets (Bartlett, 2003). In addition, the almost fixed level of exchange rate set by the stabilization plan in 1993 (which effectively implied currency appreciation) eroded the international competitiveness of Croatian producers and facilitated large increases in imports (Nikic, 2003).

Figure 6 shows the share of the main trading partners in Croatia's international trade during the transition period. It is evident that despite previously mentioned impediments, the EU15 countries remained the most important trading partners of Croatia during the entire transition period. The share of the EU15 in Croatian import and export was highest in the first years of transition when Croatia was confronted with the loss of markets in other parts of the former Yugoslavia and Eastern Europe. Within the EU15, the major trading partners were Germany and Italy, the same countries as before the transition (Table A1 in Appendix). In addition, the countries of the former Yugoslavia accounted for about $25 \%$ of Croatian exports and about $10 \%$ of its imports. The bulk of this trade took place with Slovenia and Bosnia and Herzegovina, who absorbed over $80 \%$ of Croatian trade with the region (Table A1 in Appendix). Other transition countries did not have a significant share in Croatian international trade.

The low share of CEECs in Figure 6 probably reflects the impediments to trade with these countries that were mentioned earlier. Trade with other economies from Eastern Europe was also modest and these countries accounted for less than $5 \%$ of Croatian exports and less than $10 \%$ of its imports over the entire period. To some extent these developments can be interpreted as an indicator of Croatia's strong orientation towards EU, but also they may indicate that Croatia did not succeed in regaining its position in these markets. Finally, trade with the rest of the world formed about one fifth of Croatian exports and imports.

During transition, exports from Croatia and CEECs to the rest of the world were mainly concentrated in three sectors, machinery and transport equipment, manufacturing products classified by material and miscellaneous manufactured articles (Table 6). These sectors accounted for $75 \%$ of CEECs export to the rest of the world. On the import side, the three most important import sectors in both CEECs and Croatia were the manufacturing of machinery and transport equipment, the manufacturing of products classified by material and the chemical industry.

During the transition the EU15 countries mainly imported products from the rest of the world from the three industries which were identified as the most important in the overall exports of Croatia and CEECs 


\begin{tabular}{|c|c|c|c|c|c|}
\hline \multirow[b]{2}{*}{ SITC Rev 3 Code } & \multirow[b]{2}{*}{ Description } & \multicolumn{2}{|c|}{ Export } & \multicolumn{2}{|c|}{ Import } \\
\hline & & Croatia & CEECs & Croatia & CEECs \\
\hline 0 & Food and live animals & 8.2 & 6.4 & 7.8 & 5.5 \\
\hline 1 & Beverages and Tobacco & 2.3 & 0.7 & 0.8 & 0.8 \\
\hline 2 & Crude materials, inedible, except fuels & 5.7 & 3.9 & 2.5 & 3.6 \\
\hline 3 & Mineral fuels, lubricants and related materials & 10.2 & 4.9 & 12.0 & 10.5 \\
\hline 4 & Animal and vegetable oils, fats and waxes & 0.2 & 0.2 & 0.3 & 0.3 \\
\hline 5 & Chemicals and related products, n.e.c. & 11.8 & 7.7 & 11.3 & 11.9 \\
\hline 6 & $\begin{array}{l}\text { Manufactured goods classified chiefly by } \\
\text { material }\end{array}$ & 14.3 & 22.2 & 19.0 & 19.6 \\
\hline 7 & Machinery and transport equipment & 25.4 & 36.5 & 31.9 & 36.8 \\
\hline 8 & Miscellaneous manufactured articles & 21.8 & 16.4 & 12.8 & 9.7 \\
\hline 9 & Commodities and transactions n.e.c. & 0.04 & 1.0 & 1.5 & 1.3 \\
\hline
\end{tabular}

Table 6: Sectoral distribution of international trade of Croatia and CEECs with rest of world, 1993-2007 (\%)

Source: Own calculations based on UN Comext database

\begin{tabular}{|c|c|c|c|c|c|}
\hline \multirow{2}{*}{ SITC Rev3 Code } & \multirow{2}{*}{ Description } & \multicolumn{2}{|c|}{ Export to EU15 } & \multicolumn{2}{|c|}{ Import from EU15 } \\
\hline & & Croatia & CEECS & Croatia & CEECS \\
\hline 0 & Food and live animals & 4.1 & 4.6 & 6.7 & 4.5 \\
\hline 1 & Beverages and Tobacco & 0.4 & 0.3 & 0.6 & 0.6 \\
\hline 2 & Crude materials, inedible, except fuels & 7.9 & 4.3 & 1.7 & 2.1 \\
\hline 3 & Mineral fuels, lubricants and related materials & 5.5 & 3.6 & 2.8 & 2.2 \\
\hline 4 & Animal and vegetable oils, fats and waxes & 0.1 & 0.1 & 0.3 & 0.4 \\
\hline 5 & Chemicals and related products, n.e.c. & 9.9 & 4.8 & 12.6 & 13.9 \\
\hline 6 & Manufactured goods classified chiefly by material & 14.6 & 21.2 & 19.2 & 22.9 \\
\hline 7 & Machinery and transport equipment & 23.7 & 40.1 & 39.3 & 41.9 \\
\hline 8 & Miscellaneous manufactured articles & 33.8 & 20.0 & 14.8 & 10.5 \\
\hline 9 & Commodities and transactions n.e.c. & 0.04 & 0.6 & 2.1 & 0.6 \\
\hline
\end{tabular}

Table 7: International trade of Croatia and CEECs with EU15, 1993-2007 (\%)

Source: Own calculations based on UN Comext database

(Table 7). About a third of Croatian exports to the EU15 came from miscellaneous manufactured articles. On the other hand, the most important exporting sector of the CEECs was machinery and transport equipment (40\%) Finally, the imports of these countries from the EU15 did not significantly differ from their imports from the rest of the world. It was concentrated in a few sectors, the most important being machinery and transport equipment. On the one hand, these figures can be interpreted in light of findings about the outsourcing of activities from EU15 to transition economies. However, they may also signal that intra-industry trade has an important role in the exchanges of CEECs and Croatia with the rest of the world.
Summarizing these findings it is evident that over the past two decades Croatia lost most of its initial advantage over other transition economies. Broadly speaking, it is possible to distinguish between two periods of Croatian transition: the first is characterised by the eroding competitiveness of its firms and industries (during the 1990s) and second (after 2000) when many negative trends from the previous period came to an end and the competitiveness of Croatian firms, industries and the economy as a whole started to improve. However, while it is well established and taken as stylised fact that the key role in explaining the first part of the Croatian transition belonged to the specific nature of the Croatian transition, which at that time was characterised by war, privatisation 
failures and unfavourable institutional developments, it remains unknown whether improvements in the competitiveness of Croatian firms and industries have come as a consequence of favourable developments in their environment or whether they were the results of changes in the behaviour of the firms themselves.

\section{Conclusion}

This paper reviewed the development of some important features of the Croatian economy in the course of its transition to a market economy. The investigation showed that before transition Croatia had some distinctive features in relation to other centrally-planned economies. The Croatian economic system was organized as a semi-market economy and its enterprises enjoyed a higher freedom of decision-making than their counterparts in other socialist economies. In addition, the Croatian international trade was equally balanced between East European centrally-planned economies and West European market-style economies, implying that Croatian enterprises had the experience of competing in a market oriented environment and the structure of the economy was more similar to EU15 countries than to the socialist world. However, it was also shown that in the last years of the socialist regime, Croatia struggled with hyperinflation, which suggests that Croatia was not free from the common weaknesses of centrally-planned economies despite its more liberal institutional framework and openness in trade with West European market economies. On the whole, it can be concluded that at the beginning of transition Croatia had the potential to be amongst the forerunners of transition.

The transformation of Croatia into a market-style economy started in an environment characterized by political turbulences and war, which pushed transformational recession to levels below those in most of the other transition economies, destroying a large part of its domestic economic capacities and infrastructure. Although all major reforms were pushed through at the same time as in advanced transition economies and macroeconomic stability was achieved relatively early, Croatia developed its relationships with the EU and other major international trade organisations slower than other CEECs. This, and the poor political environment, put Croatian enterprises in an unfavourable position in their traditional markets with EU15 and CEECs. As a consequence, Croatian producers turned to the markets of less developed transition economies and other countries of the world. However, the institutional framework in Croatia underwent major changes in the advanced stage of transition, characterized by a faster approach to EU and accession and membership in regional and global trade associations. $[$.

\section{References}

Babic, A. (2002). Liberalizacija Kapitalnih i Financijskih Transakcija u Hrvatskoj. Ekonomski Pregled, 53 (5-6), pp. 419-449.

Bartlett, W. (2003). Croatia: Between Europe and the Balkans. London: Routledge.

Druzic, I. (2006). A Journey Through Transition Time with Special Reference to Croatia. Zagreb: Political Culture.

DZS. Statistical Yearbook of the Republic of Croatia, various years, Zagreb: Drzavni Zavod za Statistiku (DZS).

EBRD. Transition Report., various years. EBRD.

Fischer, S., Sahay, R. and Vegh, C. (1996). Stabilization and Growth in Transition Economies: The Early Experience. Journal of Economic Perspectives, 10 (2), pp. 45-66.

Gregurek, M. (2001). Stupanj i Ucinci Privatizacije u Hrvatskoj. Ekonomski Pregled , 52 (1-2), pp. 155-188.

Gros, D., and Steinherr, A. (1995). Winds of Change, Economic Transition in Central and Eastern Europe. London and New York: Longman.

HNB. (2010). Banking System by Ownership. Retrieved 1 10, 2010, from Croatian National Bank (HNB): http://www.hnb.hr/publikac/hpublikac.htm

Lydall, H. (1984). Yugoslav Socialism: Theory and Practice. Oxford: Oxford University Press.

Nikic, G. (2003). Tranzicija u Hrvatskoj: Deset Godina Stabilnosti Tecaja iCijena. Zagreb: Binoza Press and Economic Institute Zagreb.

Payne, J. (2000). Inflationary Dynamics of a Transition Economy: The Croatian Experience. Privredna Kretanja i Ekonomska Politika , 10 (81), pp. 86-101.

Skreb, M. (1995). Building Sound Finance in Croatia: Legacies and Prospects. Croatian Economic Survey (2), pp. 61-84.

Skuflic, L. (2005). Trgovinska Liberalizacija i Troskovi Prilagodbe Europskom Trzistu: Slucaj Hrvatske. Ekonomski Pregled, 56 (12), pp. 1161-1189.

State Audit Office. (2004). Izvjesce o Radu na Provedbi Revizije Pretvorbe i Privatizacije. Zagreb: State Audit Office of the Republic of Croatia.

Thiessen, U., and Gregory, P. (2007). Modeling Structural Change: An Application to the New EU Member States and Accession Candidates. Eastern European Economics, 45 (4), pp. 5-35. 


\section{Appendix}

\begin{tabular}{|c|c|c|c|c|c|c|c|}
\hline \multicolumn{4}{|c|}{ Exports } & \multicolumn{4}{|c|}{ Imports } \\
\hline Country & 1995 & 2000 & 2007 & Country & 1995 & 2000 & 2007 \\
\hline Italy & 23,71 & 22.34 & 18.78 & Italy & 18.19 & 16.61 & 16.05 \\
\hline Bosnia and Herzegovina & 8.27 & 11.17 & 14.19 & Germany & 20.09 & 16.44 & 14.40 \\
\hline Germany & 21.52 & 14.26 & 9.84 & Russian Federation & 2.09 & 8.52 & 10.16 \\
\hline Slovenia & 13.12 & 10.83 & 8.13 & Slovenia & 10.72 & 7.94 & 5.94 \\
\hline Austria & 4.32 & 6.60 & 6.02 & Austria & 7.65 & 6.70 & 5.29 \\
\hline Serbia & $\mathrm{n} / \mathrm{a}$ & $2.42^{\mathrm{a}}$ & 5.29 & France & 2.51 & 5.53 & 3.61 \\
\hline France & 2.42 & 2.84 & 2.19 & Hungary & 2.10 & 2.33 & 2.93 \\
\hline Hungary & 1.53 & 1.35 & 2.15 & Bosnia and Herzegovina & 0.12 & 1.03 & 2.84 \\
\hline United Kingdom & 1.24 & 1.72 & 1.91 & Czech Republic & 1.96 & 2.27 & 2.16 \\
\hline Russian Federation & 3.28 & 1.28 & 1.25 & Poland & 0.60 & 1.19 & 1.96 \\
\hline
\end{tabular}

Table A1: Main trading partners of Croatia 1995-2007 (in \% according to 2007 rankings)

Source: IMF DOTS Database

aData for Serbia for 2000 refer to Serbia and Montenegro

\section{Endnotes}

'The average rate of inflation between 1985 and 1989 was 336.8\% reaching its peak in 1989 (1198.6\%).

ii The index is calculated as $\mathbb{D}_{k}=\Sigma_{i}\left(S_{T H i}-S_{\text {TUISij }}\right)^{2}$ where STE stands for share of sector $i$ in transition economy and $S_{\mathrm{EU} 15 \mathrm{i}}$ for the average share of sector $i$ in EU15. Lower values of the index indicate structural convergence between two economic entities.

iii The data are classified by SITC rev 3 classification.

iv In these sectors subsidies were justified as temporary assistance in the course of restructuring.

${ }^{\vee}$ This agreement granted Croatia unrestricted access to the EU market in all goods except fish, wine, sugar and calf-beef. In return, Croatia was expected to open its market for EU producers by the 1st of January 2008.

${ }^{v i}$ As after the declaration of independence Croatia had no reserves of its own, the Central bank started to buy foreign currency from enterprises and private persons in exchange for domestic currency. 